\title{
ARISTOTELIS
}

\section{DE GENERATIONE ANIMALIUM}

\section{LIBRI QUINQUE}

\author{
EX RECENSIONE
}

\section{IMMANUELIS BEKKERI.}

\author{
BEROLINI \\ T Y IS A C A D M I I S.
}

1MPENSIS GE. REIMERI

A. MDCCCXXIX. 
